\title{
Study on the Construction of Teachers' Morality in Ideological and Political Education Courses in Colleges of the New Era
}

\author{
Zhimin Lei, Qiao Mou \\ Sichuan Agricultural University, Chengdu, Sichuan, 611130
}

Keywords: New Age; teachers of ideological and political education; Sichuan Agricultural University

\begin{abstract}
The teacher of ideological and political theory in colleges and universities is the main worker of moral education, ideal faith education and patriotism education for college students. The construction of teacher morality has a direct impact on the effectiveness of the college and university. This paper combines the social background of the new era, and analyzes the opportunities and challenges faced by the teachers' moral construction in the ideological and political course, based on the experience of teachers' ethics in Sichuan Agricultural University, and puts forward some new ideas and new initiatives for strengthening teachers' moral construction in ideological and political education.
\end{abstract}

\section{Introduction}

General Secretary Xi Jinping said: The foundation of Colleges lies in Lideshuren. Teacher morality is a relatively stable behavioral characteristic of teachers in the teaching activities on weekdays. It is an overall reflection of teachers' thoughts and behaviors at a certain stage. We usually call them teacher professional ethics. The teachers of ideological and political theories in Colleges are the main undertakers of national ideological work, and their work targets are college students in the new era. The main duty of the ideological and political education teachers in universities is to use the classroom teaching approach through the study of Marxist theory and national policy guidelines, and to devote themselves to the ideal and faith education, patriotism education, and moral education for college students in order to cultivate a new era of Chinese characteristics. The builders needed in a socialist society. Good moral behavior plays an important role in whether ideological and political teachers can exert their ideological and political education. Therefore, strengthening the construction of teachers' morality is not only a topic for teachers themselves but also schools. This article combines the political background of the new era and the experience of teacher moral education in ideological and political teachers of Sichuan Agricultural University to further explore the opportunities, challenges, and problems faced by teachers' morality in the ideological and political reforms of new Colleges. Initiatives to seek advice from experts.

\section{Opportunities and Challenges of Teacher Morality Construction in Ideological and Political Courses in the New Era}

The new era has given new features to society. For the ideological and political teacher team, recognizing the international and domestic environment, seizing the opportunities, and meeting the challenges are the issues of their time.

First, the party and the country attach great importance to it. "The ideological and political work teams in universities have made important contributions to the development of higher education." [1]. In the new era, General Secretary Xi Jinping has taken the building of ideological and political education teams in universities to an important height. During the meeting, General Secretary Xi emphasized many times that "we must strengthen the construction of teachers' morality and ethos"[2]. At the 19th National Congress, we mentioned that the construction of high-quality teachers is mainly to strengthen the construction of teachers' morality and to guide the entire The society respects teachers and values education. Even the Central Committee of the Communist 
Party of China and the State Council's "Opinions on Reforming and Deepening the Building of the Teaching Staff in the New Era," have highlighted teachers' morality as one of the five basic principles for the reform of the teaching force, and listed the strengthening of teachers' morality and morality as an important factor in the reform of the teaching force. Measures, which all reflect the party and the country in the new era, attach importance to the construction of teachers' professional ethics and the construction and reform of college ideological and political education. The series of speeches by the leaders and the spirit of the documents passed by the state at this time have become political trends in the ideological and political education teachers of universities in the new era, and have provided political guarantees for the construction of teachers' morality in ideological and political education at Colleges.

Second, public opinion and the public attach great importance to it. The most frequently exposed on the Internet is the Shenyang incident at Peking University and the Wang Pan incident at Wuhan University of Technology. When the public is confronted with such an imbalance in teacher morality, the attitude taken by the public is uncompromising. This reflects the public's The educational undertakings and the teachers' behaviors in teaching work have all attached great importance to it, and public opinion supervision naturally becomes the intangible force that restrains and supervises teachers' behavioral norms. The incidents involving teachers' behavioral anomie and moral imbalances are like a mirror. Reflecting the neglect of college teachers' work in the construction of teachers' morality, they are also constantly reminding the teachers who are striving in the workplace: Before educating, they should first Conduct self-education to make you understand that when you use advanced culture to influence and guide students, you must have good moral qualities so that you can better assume the responsibility of helping students grow up healthily.

In the face of the keyword "teacher teacher ethics," both the national and public attitudes have shown that it is imperative to strengthen the development of teachers' moral education. This socio-political environment also offers the possibility of a new level for teachers' ethics construction in ideological and political education in universities.

First, attach importance to the construction of the humanities. The large socio-political background plays a guiding role in the construction of teachers' morality from a macro perspective. The campus cultural environment reflects the school's spiritual outlook from a micro perspective and influences the value orientation of teachers and students. Therefore, the harmonious and strong campus cultural environment plays an important role in the teacher's teacher moral construction. Sichuan Agricultural University continues to promote the inheritance and development of campus culture by cultivating and implementing the principles of socialist core values and the construction of campus culture. This has enabled the cultural positions to continue to be strengthened, the human environment has been greatly improved, and the cultural atmosphere has become more intense. In addition, Sichuan Agricultural University has placed the development of Philosophy Science in an important position, held the Philosophy Science Promotion Association, and developed Philosophy majors of the Philosophy and Philosophy as an emphasis on the important position of the faculty in Sichuan University's ideological and political theory class in the school. The sense of belonging and teaching enthusiasm of the teachers of Sichuan Agricultural University ideological and political teachers led ideological and political teachers to put themselves into teaching and research work with a more positive attitude and dedicated their youth and sweat to the growth of Chuanong University.

Second, adhere to the dominant position of teachers and students. The school adheres to the principal position of teachers and students, perfects the system of teachers' representative conference and school representative meeting, implements information disclosure methods, and expands democratic management and supervision channels. Play the role of a bridge link in school organization. For example, the full use of Chuanongda's trade unions, the Communist Youth League, women's committees and other organizations to communicate functions, to better reflect the teachers and students voice, safeguard the legitimate rights and interests of teachers and students, and promote the building of grassroots democracy. Through such democratic channels and 
democratic methods, the status of masters of Sichuan Agricultural University staff has been consolidated, and the sense of belonging among teachers has been enhanced. As a result, more ideological and political teachers have been paying attention to students, schools, and society at the same time. Sichuan Agricultural University is a microcosm of the construction of a good campus culture environment in many Colleges to strengthen the construction of teacher ethics. At the same time, it has made other more Colleges realize that a good school style of study can be another opportunity for the construction of teachers' morality in ideological and political programs in universities in the new era.

In the increasingly global context, the influence of foreign ideological trends has increasingly become a major challenge for teachers of ideological and political teachers. China has ushered in the 40th anniversary of reform and opening up in 2018. Xi has repeatedly stressed that China will not stop the pace of opening to the outside world. While China is selling more and more of its economic and cultural products to various parts of the world, it will also be influenced by the cultural concept of Western countries. The concept of "universal value," "neo-liberalism," and "historical nihilism" advocated by Western capitalist countries is contrary to the values advocated by Chinese society. The ideological and political courses in colleges engaged in the work of socialist ideology It is impossible for teachers to completely avoid being influenced by western values in globalization. In this process of influence, the corrupt thoughts of the West are likely to erode the brains of ideological and political theory teachers and shake their socialist beliefs. The ideological and political education teachers in Colleges, as builders and stalwarts of national ideology, do not disseminate discourses that discredit socialism and endanger the nation, and do not express anger and anger in the classroom. This is the political bottom line that ideological teachers in universities should abide by. And moral bottom line. The ideological and political teachers are faced with the deepening of the country's openness and the strengthening of external influence in the new era. The construction of the teacher's morality will become a more arduous task.

The ideological and political teachers in Colleges are the bearers who help college students establish beliefs in life and strengthen their ideals and beliefs. They are paving the way for college students before entering the society. Therefore, the moral qualities of ideological and political teachers will determine whether they can provide the talents they really need. To the community. General Secretary Xi pointed out in the report of the 19th National Congress: China has entered a new era. The characteristics of China's economic development have changed from high-speed development to high-quality development. In order to overcome the current bottleneck of national economic development, we must implement innovation-driven development. Strategy to promote the transformation of Chinese manufacturing to China. As a result, a large number of innovative talents are needed, which puts higher requirements on the shaping of society's outstanding talents university ideological and political teachers. First of all, during the teaching process, teachers of ideological and political education departments in universities only continuously and practically understand the social status quo and student characteristics to enrich teaching content and innovative teaching methods, increase student satisfaction with the curriculum, and enable students to form a good style of study and enhance Students' curiosity and sense of innovation in the new era. Second, ideological and political teachers with good moral cultivation and ethical behavior can influence their students subtly and make students form a lofty spiritual realm so that they can nurture the builders they really need.

\section{Problems in the Construction of Teacher Morality of Ideological and Political Education in New Era}

In the new era, based on the country's and the society's continuous attention to teacher's teacher morality construction, as well as teachers' continuous review, continuous learning, and continuous improvement of themselves, the status of teachers' morality as presented in the society as a whole is generally good. There are still some problems in the construction of German morality:

Just as Xi Xie's secretary metaphorically stated, ideals and beliefs are part of the survival and development of human beings. Without human ideals and beliefs, one cannot accomplish their 
mission. For ideological and political teachers, their mission is to complete moral education, ideals and beliefs education, and patriotism education for college students in order to nurture outstanding young people committed to the construction of a socialist society with Chinese characteristics. However, with the establishment of the socialist market economic system, the influx of various market economy components and diversified ideological trends, some ideological and political teachers have downplayed the beliefs in communism and patriotism that should be adhered to, not only for the teaching that they are responsible for. The task is perfunctory, and the attitude toward academic research is still relatively lax, let alone to focus on student learning and growth. On the contrary, when it comes to personal interests, it must be more ambiguous and individual desires swell. The root cause of these phenomena is the lack of ideals and beliefs. When ideological and political teachers lack the firm belief in serving students, serving the people, and serving the society, it is easy to run contrary to a ideological teacher with higher moral cultivation and strong teaching ability. Then there are teachers similar to those exposed on the Internet. Moral imbalances and misconduct will not be an example.

Having a convincing theoretical level and moral quality is a basic prerequisite for a qualified ideological teacher. However, because of the influence of its own factors, there are also many teachers in this excellent team that lack good teachers' morality. The reasons are as follows: Lack of professionalism. Answering doubts to students is the fundamental responsibility of the teacher. In the era of big data, college students have a stronger sense of autonomy. In the face of pure theoretical ideological and political studies, the contradictions displayed by the students are becoming more apparent. Therefore, some ideological and political teachers in Colleges are facing arduous tasks in the classroom. When the students' attitudes toward learning are not positive, they will gradually develop a negative and slackening mood. As a result, the task of facing the school cannot be completed in time and the teaching results are not significant. The main reason is the lack of teaching as their responsibility, the students as a fundamental professionalism; teaching and education are separated. "Teaching" and "cultivating people" are the right and left hands of an excellent teacher to complete the teaching work. They are indispensable. However, in the actual teaching of ideological and political theory courses, some teachers do not fully devote themselves to teaching work without fully recognizing their own responsibilities, and lack knowledge of the students' current level of ideological and political education. Failure to fully grasp the rules of student education and self-education, internalization and externalization, the ideological and political education teachers' moral education work is difficult to carry out or is carried out with little success. If the work done in moral education is not enough, then the learning effectiveness of many students' professional courses will not be obvious.

As the saying goes, "No rules are not available," and the school's perfect management system and sound evaluation mechanism are an important part of the ideological and political teacher team's construction of teachers' morality. However, many institutions of higher education need to evaluate and supervise teacher ethics. perfect. For example, the evaluation of school titles and the evaluation mechanism for promotion positions are not scientific or systematic. Many Colleges evaluate the teachers of ideological and political education just to see the archived materials, such as the publication of the paper, the contribution of scientific research and so on. This leads many ideological and political teachers in universities to pay more attention to scientific research and intellectual education for students. This also makes it easier for some ideological and political teachers to forget their original role-the main worker of moral education for college students. This makes the evaluation standard of the teacher morality useless. . The standard of teacher's morality assessment is a "soft index". Many Colleges will not pay attention to or even disregard the teachers' moral assessment standards when they encounter teachers' morality. The reason for inertia recognition and interpersonal relationships often lacks actual investigation and consideration of the evaluation of the ideological and political teacher team, which deviates from the real purpose of the teacher moral evaluation. 


\section{New Initiatives for Teacher Morality Construction of Ideological and Political Education}

In the face of opportunities, challenges and existing problems in the new era, it is imperative for universities and colleges to take practical and feasible measures in light of their actual situation.

Ideals and beliefs are people's practical concepts that are formed in combination with their actual needs. They come from people's real life and guide people's practical activities. Educate people to educate themselves. If ideological and political teachers don't cultivate ideals and beliefs for themselves, how can they help shoulder the burden of helping ideals and beliefs of college students in the new era? Therefore, it is imperative to strengthen the cultivation of teachers' ideals and beliefs. The ideological and political teachers in universities are strengthening the cultivation of ideals and beliefs by deepening their systematic study of Marx, Leninism, Mao Zedong Thought, and the theoretical system of Chinese characteristics with socialism, especially the learning and exploration of the socialist ideology with Chinese characteristics in the new era of Xi Jinping. While cultivating his own unique insights, he firmly established the common ideals of communism and the common ideal of socialism with Chinese characteristics, inherited the fine traditions of the revolutionary party of the older generation, based on serving the socialist society with Chinese characteristics and serving socialist college students, keeping in mind the mission and never forgetting the early days. .

In 1956, Sichuan Agricultural University established an independent school in Ya'an City. The opening speech of Mr. Yang Kaiqu, the first dean, has been inspiring since then: He mentioned that the prospects for China's agricultural development are incalculable in light of the special topography and terrain in Sichuan. During this development process, In the middle, Sichuan farmers must commit themselves to shouldering the burden of cultivating our country's socialist agricultural constructors and continuing to march to the mountain agriculture, forestry, and animal husbandry science. It is also such a spirit that continues to inspire the peasants to forge ahead in their hearts and forge ahead, enabling the peasants to enjoy the spiritual wealth of "pursuing the truth, benefiting the society, and striving to become stronger" that has been forged through centuries of vicissitudes. This valuable wealth is a concentrated expression of the spirit of the Sichuan Agricultural University, but also the unremitting pursuit of the teachers of the Sichuan Agricultural University ideological and political classes.

"College teachers should insist that educators receive education first” [4]. Marx pointed out that people's sense of concept is determined by the environment in which people are living, and society in the new era is rapidly developing and changing. Only by strengthening the education and training of ideological and political teachers and changing their concepts can ideological and political teachers be The changes of the times constantly enrich the knowledge content, improve the knowledge structure, and innovate educational methods, so as to improve the professionalism and professionalism of ideological and political teachers to meet the needs of students in the new era and society in the new era. Therefore, ideological and political education teachers in universities should adapt to local conditions and participate in multi-channel education and training. When universities and colleges make full use of opportunities and platforms to strengthen the education and training of ideological and political teachers, they must not only focus on improving teachers' "hard power" - teaching ability and scientific research level, but also focus on improving "soft power" of ideological and political teachers. - Moral cultivation and ideological quality. Only the ideological and political education teachers in the university have the correct political direction and the spirit of selfless dedication. Only in this way can the Guangcai University become more active in the construction of socialism with Chinese characteristics.

In recent years, the teachers of the Marxist Academy, which is responsible for the teaching of the Sichuan Agricultural University's ideological work class, have carried out ideological and political lesson teacher training in the school. The training methods are various. For example, teachers use the after-school hours to hold topical symposiums, exchange gains and shortcomings in the teaching process, share experiences, learn from each other, and make progress together; they also conduct field research and visits during the holidays; teachers also participate in online courses. Learning 
and training, making full use of network resources to expand and enhance themselves; the college also as many as more than 20 teachers went to Beijing, Xiamen and other places to participate in the course training and inter-school exchanges. The purpose of these education and training is to continue the teachers' continuous learning and commit themselves to the building of teachers' moral character in Sichuan Province's ideological and political teacher team.

The establishment of a sound and stimulating mechanism in Colleges is not only an important part of the improvement of the ideological and political teaching staff moral construction mechanism, but also a powerful measure to enhance the comprehensive quality of ideological and political theory teachers. Through improving the incentive and supervision mechanisms, the ideological and political teacher moral evaluation is an important part of appraising, appraising, and running for positions. For example: Establish an unscheduled inspection and notification mechanism led by the headteacher. The squad established with the headteacher as the team leader randomly patrolled the classroom teaching behaviors of ideological and political teachers, affirmed and praised well-performed teachers, made public criticisms of teachers who performed poorly, and established a college-level supervisory system. The teachers at the college level establish a team of supervisors of teachers' morality according to a certain percentage, use visits, investigations, etc. to regularly evaluate the teacher morality of ideological and political teachers, and establish files; and establish a feedback mechanism for students at the end of the period. The students of the ideological and political education teachers' class are based on the evaluation standards of teachers' morality of the school. Through the observation of teachers' language and behavior in the daily teaching process, and even the understanding of life, the students of the ideological and political class are anonymously taught. Evaluation, the school's satisfaction with the students and how much satisfaction as an important basis for teacher awards or titles. In this way, whether school leaders, colleagues, or students are involved in the supervision and motivation of teachers' ethics, the system of ethics and morality of teachers is constantly improving while being more systematic, scientific, and democratic.

\section{Conclusion}

The ideological teacher teacher morality is the star of the new era of college students, and plays an important guiding role in the development of college students. The ideological and political teacher morality is a banner, which is a manifestation of the good appearance of the school and society. The construction of a good team of teachers can not be accomplished by the efforts of one party alone. Therefore, strengthening teachers' morality in ideological and political education is a task that should be shared by society, schools, and teachers themselves. This article starts with the opportunities and challenges of teachers' moral construction in the ideological and political education under the social environment in the new era. Based on the existing problems in the construction of teacher ethics, combined with some experiences in the construction of teachers' ethics in Sichuan Agricultural University, it is proposed to strengthen ideological and political education. The new thinking and new measures in the construction of the teacher's moral education team hope that we can make a little effort to build a team of ideological and political theory teachers who meet the needs of the new era.

\section{References}

[1] [2][4] Xi Jinping. The ideological and political work runs through the entire process of education [Z]. National Conference on Ideological and Political Work in Colleges, Beijing, 2016.

[3] Xi Jinping. Nineteenth Congress Report [Z]. Nineteenth National Congress, Beijing, 2017.

[5] Propaganda Department of the Central Committee of the Communist Party of China and Ministry of Education. Opinions on Further Strengthening the Construction of the Ideological and Political Theory Teachers in Colleges. (JSJ [2008] No. 5), 2008.

[6] Dai Wei. On the existing problems and countermeasures in the construction of young teachers' 
moralities in Colleges [J]. Shanxi Youth 2016 (15).

[7] Zheng Yongting. Modern Ideological and Political Education [M]. People's Education Press, 2006.

[8] Zuo Wei. Problems and Countermeasures Faced by Teachers' Professional Moral Construction[J]. Journal of Changchun Teachers College,2003(03). 